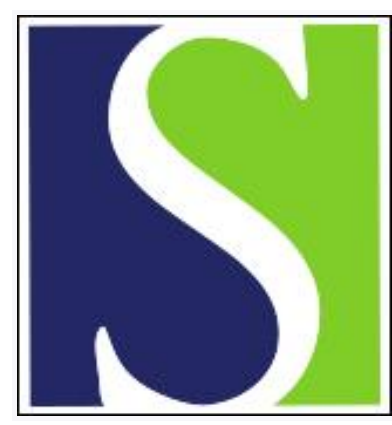

Scand J Work Environ Health 1992;18(1):11-17

https://doi.org/10.5271/sjweh.1613

Issue date: 28 Feb 1992

Maternal occupational exposure and congenital malformations.

by Cordier S, Ha MC, Ayme S, Goujard J

Affiliation: National Institute for Health and Medical Research (INSERM), Unit 170, Villejuif, France.

This article in PubMed: www.ncbi.nlm.nih.gov/pubmed/1553508 


\title{
Maternal occupational exposure and congenital malformations
}

\author{
by Sylvaine Cordier, $\mathrm{PhD},{ }^{1}$ Marie-Catherine $\mathrm{Ha}, \mathrm{MD},{ }^{1}$ Segolene Ayme, $\mathrm{MD},{ }^{2}$ Janine Goujard, $\mathrm{MD}^{3}$
}

\begin{abstract}
CORDIER S, HA M-C, AYME S, GOUJARD J. Maternal occupational exposure and congenital malformations. Scand J Work Environ Health 1992;18:11-7. A case-referent study was conducted to assess the risk of congenital malformations in relation to maternal occupational exposure before and during pregnancy. Three hundred and twenty-five cases of major malformations and 325 normal (at birth) referents identified in 15 maternity hospitals were included in the study. The occupational history obtained from an interview of the mother was blindly reviewed by an industrial hygienist who assessed the presence of chemical exposure and the probability of exposure. The results suggested that mothers of the case children with oral clefts were more often exposed to solvents during pregnancy [odds ratio (OR) $7.9,90 \%$ confidence interval $(90 \% \mathrm{CI}) 1.8-44.9 \mathrm{]}$ and worked more often as cleaners (four cases, no referents). Digestive anomalies (OR $11.9,90 \%$ CI 2.0-149) and multiple anomalies (OR 4.5, 90\% CI 1.4-16.9) were also associated with occupational exposure to solvents at work. These results were not modified when differences in maternal age, area of residence, and socioeconomic status were taken into account.
\end{abstract}

Key terms: cleaning work, digestive anomalies, multiple anomalies, oral clefts, organic solvents.

The role of maternal exposure to exogenous factors in the etiology of congenital malformations has been demonstrated through the action of some infections or following drug intake during pregnancy. Accidental heavy exposure to methylmercury raised concern about the role of environmental factors $(1,2)$. Since then, surveillance systems and ad-hoc studies have looked for undiscovered toxic agents, especially in the work environment (3-5).

The role of exposure to organic solvents has been studied on several occasions. Case-referent studies on central nervous system anomalies (6) and oral clefts (7) in Finland have shown associations, and more recently a Canadian study (8) found a link between exposure to aromatic solvents and urinary anomalies. An occupational group which was specifically studied because of a wide range of chemical exposures was laboratory workers. Evidence of a link between laboratory work and malformations of the gastrointestinal tract has been reported in some studies $(9,10)$, but not confirmed in others (11).

Other occupational groups of interest are those involving possible chemical exposure and representing a sizeable part of the female work force in the general population of most countries (eg, hospital or health care workers). Several specific exposures have been studied (anesthetic gases, antineoplastic drugs, disin-

\footnotetext{
${ }^{1}$ National Institute for Health and Medical Research (INSERM), Unit 170, Villejuif, France.

2 INSERM, Unit 242, Marseille, France.

${ }^{3}$ INSERM, Unit 149, Paris, France.
}

Reprint requests to: Dr S Cordier, INSERM U 170; 16, Avenue P Vaillant-Couturier; F-94807 Villejuif Cedex; France. fectants), but there is no conclusive evidence of an increased risk of congenital malformations $(12,13)$.

Taking advantage of the registration of congenital malformations in two important areas in France, we decided to conduct a case-referent study on major congenital malformations grouped into homogeneous systems in relation to maternal occupational exposure. The malformations specifically studied were central nervous system anomalies, urinary anomalies, oral clefts, and digestive anomalies. Since it appears that multiple anomalies might be sensitive indicators of new teratogens in the environment (14), this group was also studied as a whole.

Occupational exposures under more specific scrutiny were exposure to organic solvents and laboratory or medical work. In a second step, frequent exposures and occupational groups were studied in a more exploratory way.

\section{Subjects and methods}

A case-referent study was conducted between 1984 and 1987 in two areas in France (Paris and Marseille), including 15 maternity hospitals (seven in Paris, eight in Marseille) in part of the registration area. The cases were all conceptuses with major congenital malformations to mothers attending one of the study hospitals. Conceptuses eligible were liveborn babies, stillbirths, or fetuses of any gestational age resulting from therapeutic abortion. Only major defects detected prenatally or during the perinatal period (from birth to $7 \mathrm{~d}$ after birth) were included (table 1). Malformations of known environmental or familial origin were excluded (eg, fetal alcohol syndrome). 
Table 1. Malformations included in the study. (BPACD $=$ British Paediatric Association Classification of Diseases)

\begin{tabular}{ll}
\hline BPACD code & Malformation \\
\hline $740.0 / 1$ & Anencephaly including craniorachischisis \\
740.3 & Iniencephaly \\
741. & $\begin{array}{l}\text { Myelomeningocele, spina bifida, excluding } \\
\text { spina bifida occulta }\end{array}$ \\
742.0 & Encephalocele \\
742.1 & Microcephaly \\
742.26 & Holoprosencephaly \\
742.3 & Congenital hydrocephaly \\
& $\begin{array}{l}\text { Specified malformation of heart and great ves- } \\
\text { sels, excluding malposition of the heart, cardio- }\end{array}$ \\
& $\begin{array}{l}\text { myopathy, conduction disorders and dyshyth- } \\
\text { mia without heart malformation, excluding }\end{array}$ \\
& $\begin{array}{l}\text { patent ductus, arteriosus in premature (less } \\
\text { than } 37 \text { weeks of gestation) and in low birth- }\end{array}$ \\
weight babies (less than 2500 g), excluding un- \\
specified cardiac malformation
\end{tabular}

One reference baby, normal at birth, was selected for each case. Referents were born immediately after the cases in the same maternity ward. If, for instance, the selected mother could not be interviewed because she left the maternity ward before the interview could take place, the next baby was chosen. The following medical data concerning birth or abortion were abstracted from medical records: date, gender, status (liveborn, stillborn, abortion), weight, gestational age, description of malformations, results of additional inquiries (karyotypes, necropsies).

Mothers of the cases and referents were interviewed at the hospital according to a structured questionnaire on sociodemographic variables such as age; place of birth and residence; familial, medical and obstetrical history; pregnancy history, including infections and drug treatment; tobacco and alcohol consumption; hobbies; and a complete occupational history (dates, industrial activity, specific occupations with a description of task and products handled for the job held during pregnancy). The mother also had to answer several questions concerning the father (tobacco and alcohol consumption, occupational history, and hobbies). The interviews of the case and the corresponding reference parent were always done by the same person. The socioeconomic status of the mother and father were estimated from the occupation at the time of pregnancy, or just before, and classified into the following four groups: (i) never employed, (ii) professional or managerial workers, (iii) clerks, sales or service workers, and (iv) production or agricultural workers.

The occupational histories of the mothers before and during pregnancy were then blindly reviewed by an industrial hygienist who assessed the presence of chemial exposure for each work period and estimated the frequency as follows: (i) exposed less than $10 \%$ of the worktime, (ii) exposed between 10 and $50 \%$ of the worktime, (iii) exposed more than $50 \%$ of the worktime. Exposure to solvents was defined according to the following two classes of products: "pure" solvents (ie, white spirit, trichloroethylene, alcohols, ethers, etc) and products usually containing solvents, such as paints, glues, varnishes, dyes, inks, and the like. The assessment of exposure during pregnancy was made from the mother's description of her job at the beginning of pregnancy. Questions were asked about leaves during pregnancy. It was not possible to assess the duration of exposure during pregnancy with precision. We did assume however that the possible exposures were present at least at the beginning of pregnancy, that is, during the risk period for structural malformations. The probability of exposure for each job during the whole worklife was also estimated.

Each malformation was first coded according to the British Paediatric Association Classification of Diseases (BPACD 1979), but, as most of them were present in only a few cases, a second code was defined to allow the grouping of anomalies. The following nine classes of defects were constituted: chromosomal anomalies, defects of the musculoskeletal system, genital and urinary anomalies, defects of the central nervous system, defects of the digestive system, cleft lip and palate, cardiac anomalies, other single anomalies, and multiple anomalies. Multiple anomalies explained by a sequence of events, such as Potter sequence, were considered a single anomaly (eg, renal anomaly in Potter sequence). Single or multiple anomalies due to a mendelian disorder were excluded.

We retained the matching of cases and referents according to hospital of birth in the analysis by stratifying according to the area of residence of the mother at the time of inclusion in the study as follows: (i) hospital in Paris and residence in Paris, (ii) hospital in Paris and residence outside Paris, (iii) hospital in 
Marseille. Odds ratios for sociodemographic or medical characteristics and life-style factors and their confidence intervals were estimated with an unconditional logistic regression adjusting for area of residence.

Occupational exposures were studied for each group of malformations and its reference group, restricting the analysis first to mothers employed during pregnancy and then to mothers ever employed. Solvents was the main exposure of interest, and hospital work was the main occupational group studied. The groups of anomalies for which a specific link with the exposures was tested were central nervous system anomalies, urinary anomalies, oral clefts, and digestive anomalies. Other associations including other groups of anomalies and exposures or occupational groups which were frequently represented in the sample (detergents, disinfectants, work as a cleaner) were also studied in a more exploratory way. In the analysis of occupational exposures, potential confounders such as maternal age ( $\leq 35$ years, $>35$ years), socioeconomic status of the mother, and area of residence of the mother were included in the multivariate analysis. Exact conditional maximum likelihood estimates of the odds ratio and mid-p corrected confidence intervals were computed with StatXact software for exact nonparametric inference (15).

Three hundred and twenty-five case-referent pairs were interviewed between 1984 and 1987, 244 in Paris and 81 in Marseille. The final set of anomalies and the percentage of therapeutic abortions in each group are listed in table 2. Some anomalies not listed in table 1 are present because they were associated with other major defects in the original list of inclusion.

\section{Results}

On the average, maternal age did not differ significantly between the cases and referents, but the proportion of mothers aged $>35$ years was significantly higher among the cases (table 3 ).

The mothers of cases originated more often from North Africa and Southern Europe than the mothers of referents, but not significantly. The mothers of referents more often had a professional activity at the time of pregnancy than did the mothers of cases.

Table 3 shows that fathers of cases were more often service or production workers and less often worked as professional or technical workers than the referents did. This difference was not significant if the sample was restricted to Marseille. Among the mothers, the tendency was the same but not statistically significant.

The mothers of cases more often reported three or more live births than the mothers of the referents (table 4). This result correlates with some previously mentioned differences: a higher proportion of mothers aged $>35$ among the cases, geographic origin (more mothers immigrating from North Africa and Southern Europe among the cases), higher proportion of mothers with a professional activity among the referents.

There was no statistically significant difference between the mothers of cases and referents according to antecedents of spontaneous abortion, stillbirth, or therapeutic abortion. The mothers of cases reported more infections (mostly cold syndromes) during pregnancy than did the mothers of referents. These reports however had not been confirmed by a physician and were not specific to one type of malformation. The propor-

Table 2. Number and status of the malformations included in the study by group of malformations.

\begin{tabular}{|c|c|c|c|c|}
\hline \multirow{3}{*}{ Group of malformations } & \multirow{3}{*}{$\begin{array}{c}\text { Total } \\
\text { (N) }\end{array}$} & \multicolumn{3}{|c|}{ Status } \\
\hline & & \multirow{2}{*}{$\begin{array}{c}\text { Birth } \\
(\mathrm{N})\end{array}$} & \multicolumn{2}{|c|}{ Therapeutic abortions } \\
\hline & & & $\mathrm{N}$ & $\%$ \\
\hline I. Chromosomal anomalies & 91 & 32 & 59 & 64.8 \\
\hline II. Musculoskeletal anomalies & 85 & 61 & 24 & 28.2 \\
\hline $\begin{array}{l}\text { Abdominal wall defects } \\
\text { Limb reduction defects } \\
\text { Limb position deformities } \\
\text { Polydactyly-syndactily } \\
\text { Other }\end{array}$ & $\begin{array}{r}51 \\
20 \\
5 \\
8 \\
10\end{array}$ & & & \\
\hline III. Genital and urinary anomalies & 51 & 26 & 25 & 49.0 \\
\hline IV. Central nervous system anomalies & 83 & 23 & 60 & 72.3 \\
\hline $\begin{array}{l}\text { Neural tube } \\
\text { Microcephaly } \\
\text { Other }\end{array}$ & $\begin{array}{r}69 \\
10 \\
4\end{array}$ & & & \\
\hline V. Digestive system anomalies & 22 & 17 & 5 & 22.7 \\
\hline VI. Cleft lip and cleft palate & 29 & 23 & 6 & 20.7 \\
\hline VII. Cardiac anomalies & 30 & 15 & 15 & 50.0 \\
\hline VIII. Other single anomalies & 16 & 6 & 10 & 62.5 \\
\hline IX. Multiple anomalies & 51 & 28 & 23 & 45.1 \\
\hline Total & 325 & 166 & 159 & 48.9 \\
\hline
\end{tabular}


Table 3. Sociodemographic characteristics of the cases and referents.

\begin{tabular}{|c|c|c|c|c|c|c|}
\hline \multirow[t]{2}{*}{ Characteristic } & \multicolumn{2}{|c|}{$\begin{array}{c}\text { Cases } \\
(\mathrm{N}=325)\end{array}$} & \multicolumn{2}{|c|}{$\begin{array}{l}\text { Referents } \\
(\mathrm{N}=325)\end{array}$} & \multirow{2}{*}{$\begin{array}{l}\text { Odds } \\
\text { ratio }\end{array}$} & \multirow{2}{*}{$\begin{array}{l}95 \% \\
\text { confidence } \\
\text { interval }\end{array}$} \\
\hline & $N$ & $\%$ & $\mathrm{~N}$ & $\%$ & & \\
\hline \multicolumn{7}{|l|}{ Age of the motherb } \\
\hline $\begin{array}{l}\leq 35 \text { years } \\
>35 \text { years } \\
\text { Unknown }\end{array}$ & $\begin{array}{r}231 \\
90 \\
4\end{array}$ & $\begin{array}{r}72.0 \\
28.0 \\
.\end{array}$ & $\begin{array}{r}265 \\
49 \\
11\end{array}$ & $\begin{array}{c}84.4 \\
15.6 \\
.\end{array}$ & $\begin{array}{l}1.0 \\
2.1 \\
.\end{array}$ & $1.4-3.2$ \\
\hline \multicolumn{7}{|l|}{ Geographic origin of the mother } \\
\hline $\begin{array}{l}\text { France } \\
\text { North Africa } \\
\text { Southern Europe } \\
\text { Other } \\
\text { Unknown }\end{array}$ & $\begin{array}{r}232 \\
28 \\
17 \\
38 \\
10\end{array}$ & $\begin{array}{r}73.6 \\
8.9 \\
5.4 \\
12.1 \\
.\end{array}$ & $\begin{array}{r}244 \\
17 \\
8 \\
42 \\
14\end{array}$ & $\begin{array}{r}78.4 \\
5.5 \\
2.6 \\
13.5 \\
\cdot\end{array}$ & $\begin{array}{l}1.0^{c} \\
1.9 \\
2.2 \\
1.0 \\
.\end{array}$ & $\begin{array}{l}1.0-3.5 \\
0.9-5.2 \\
0.6-1.6\end{array}$ \\
\hline \multicolumn{7}{|l|}{ Socioeconomic status of the father } \\
\hline $\begin{array}{l}\text { Never employed } \\
\text { Professional, managerial workers } \\
\text { Clerks, sales and service workers } \\
\text { Production and agricultural workers } \\
\text { Unknown }\end{array}$ & $\begin{array}{r}4 \\
112 \\
92 \\
112 \\
5\end{array}$ & $\begin{array}{r}1.2 \\
35.0 \\
28.8 \\
35.0\end{array}$ & $\begin{array}{r}8 \\
153 \\
76 \\
79 \\
9\end{array}$ & $\begin{array}{r}2.5 \\
48.4 \\
24.1 \\
25.0\end{array}$ & $\begin{array}{l}0.8 \\
1.0^{\mathrm{c}} \\
1.7 \\
2.0\end{array}$ & $\begin{array}{l}0.2-2.6 \\
1.2-2.6 \\
1.4-3.0\end{array}$ \\
\hline \multicolumn{7}{|c|}{$\begin{array}{l}\text { Employment of the mother at the beginning } \\
\text { of pregnancy }\end{array}$} \\
\hline $\begin{array}{l}\text { No } \\
\text { Yes } \\
\text { Unknown }\end{array}$ & $\begin{array}{r}130 \\
193 \\
2\end{array}$ & $\begin{array}{c}40.3 \\
59.8 \\
.\end{array}$ & $\begin{array}{r}98 \\
223 \\
4\end{array}$ & $\begin{array}{c}30.5 \\
69.5 \\
.\end{array}$ & $\begin{array}{l}1.0 \\
0.7 \\
.\end{array}$ & $0.5-0.9$ \\
\hline \multicolumn{7}{|l|}{ Socioeconomic status of the mother } \\
\hline $\begin{array}{l}\text { Never employed } \\
\text { Professional, managerial workers } \\
\text { Clerks, sales and service workers } \\
\text { Production and agricultural workers } \\
\text { Unknown }\end{array}$ & $\begin{array}{r}54 \\
94 \\
161 \\
14 \\
2\end{array}$ & $\begin{array}{r}16.7 \\
29.1 \\
49.9 \\
4.3\end{array}$ & $\begin{array}{r}43 \\
116 \\
150 \\
8 \\
8\end{array}$ & $\begin{array}{r}13.6 \\
36.6 \\
47.3 \\
2.5 \\
.\end{array}$ & $\begin{array}{l}1.6 \\
1.0 \\
1.3 \\
2.0 \\
.\end{array}$ & $\begin{array}{c}1.0-2.6 \\
0.9-1.9 \\
0.8-5.1\end{array}$ \\
\hline
\end{tabular}

Table 4. Obstetrical characteristics and life-style factors of the mothers.

\begin{tabular}{|c|c|c|c|c|c|c|}
\hline \multirow[t]{2}{*}{ Characteristic or factor } & \multicolumn{2}{|c|}{$\begin{array}{c}\text { Cases } \\
(\mathrm{N}=325)\end{array}$} & \multicolumn{2}{|c|}{$\begin{array}{l}\text { Referents } \\
(\mathrm{N}=325)\end{array}$} & \multirow{2}{*}{$\begin{array}{l}\text { Odds } \\
\text { ratio }\end{array}$} & \multirow{2}{*}{$\begin{array}{c}95 \% \\
\text { confidence } \\
\text { interval }\end{array}$} \\
\hline & $N$ & $\%$ & $\mathrm{~N}$ & $\%$ & & \\
\hline \multicolumn{7}{|l|}{ Previous live births } \\
\hline $\begin{array}{l}0 \\
1 \\
2 \\
\geq 3 \\
\text { Unknown }\end{array}$ & $\begin{array}{r}143 \\
90 \\
52 \\
33 \\
7\end{array}$ & $\begin{array}{c}45.0 \\
28.3 \\
16.3 \\
10.4 \\
.\end{array}$ & $\begin{array}{r}141 \\
110 \\
50 \\
15 \\
9\end{array}$ & $\begin{array}{r}44.6 \\
34.8 \\
15.8 \\
4.8\end{array}$ & $\begin{array}{l}1.0 \\
0.8 \\
1.0 \\
2.2 \\
\cdot\end{array}$ & $\begin{array}{c}0.6-1.2 \\
0.6-1.6 \\
1.1-4.2 \\
\cdot\end{array}$ \\
\hline \multicolumn{7}{|l|}{ Previous spontaneous abortions } \\
\hline $\begin{array}{l}0 \\
1 \\
\geq 2 \\
\text { Unknown }\end{array}$ & $\begin{array}{r}251 \\
52 \\
15 \\
7\end{array}$ & $\begin{array}{r}78.9 \\
16.4 \\
4.7 \\
\cdot\end{array}$ & $\begin{array}{r}241 \\
54 \\
20 \\
10\end{array}$ & $\begin{array}{r}76.5 \\
17.1 \\
6.4 \\
.\end{array}$ & $\begin{array}{l}1.0 \\
0.9 \\
0.7\end{array}$ & $\begin{array}{c}0.6-1.4 \\
0.4-1.4 \\
.\end{array}$ \\
\hline History of therapeutic abortion & 10 & 3.1 & 13 & 4.1 & $0.7^{b}$ & $0.3-1.7$ \\
\hline History of stillbirth & 11 & 3.5 & 7 & 2.2 & $1.5^{b}$ & $0.6-3.9$ \\
\hline Infection during pregnancy & 65 & 20.4 & 40 & 12.8 & $1.7^{\mathrm{b}}$ & $1.1-2.7$ \\
\hline Drugs during pregnancy & 162 & 49.8 & 150 & 46.1 & $1.2^{\mathrm{b}}$ & $0.9-1.6$ \\
\hline Tobacco during pregnancy & 66 & 20.5 & 79 & 24.6 & $0.8^{b}$ & $0.6-1.2$ \\
\hline Alcohol during pregnancy & 37 & 11.5 & 44 & 13.7 & $0.8^{b}$ & $0.5-1.3$ \\
\hline
\end{tabular}

a Odds ratio adjusted for area of residence of the mother.

b Reference category = factor absent $(O R=1.0)$.

tions of mothers reporting regular consumption of tobacco or alcohol or drug use during pregnancy were similar for the case and reference groups.
Tables 5 and 6 present the exact adjusted odds ratios and their confidence intervals in association with several occupational exposures during pregnancy for 
Table 5. Exposure and work during pregnancy for mothers of children with malformations of the central nervous system, urinary anomalies, oral clefts, and digestive anomalies. ( $\mathrm{C}=$ cases, $\mathrm{R}=$ referents, $\mathrm{OR}=0 \mathrm{dds}$ ratio, $90 \% \mathrm{Cl}=90 \% \mathrm{confidence}$ interval)

\begin{tabular}{|c|c|c|c|c|c|c|c|c|c|c|c|c|c|c|c|c|}
\hline \multirow[b]{2}{*}{ Exposure } & \multicolumn{4}{|c|}{$\begin{array}{c}\text { Central nervous system } \\
\text { (83 pairs) }\end{array}$} & \multicolumn{4}{|c|}{$\begin{array}{l}\text { Urinary } \\
\text { (51 pairs) }\end{array}$} & \multicolumn{4}{|c|}{$\begin{array}{l}\text { Oral clefts } \\
\text { (29 pairs) }\end{array}$} & \multicolumn{4}{|c|}{$\begin{array}{l}\text { Digestive } \\
\text { (22 pairs) }\end{array}$} \\
\hline & $\begin{array}{c}C \\
(N= \\
\left.50^{b}\right)\end{array}$ & $\begin{array}{c}R \\
(N=b) \\
\left.57^{b}\right)\end{array}$ & $O R^{a}$ & $90 \% \mathrm{Cl}$ & $\begin{array}{c}C \\
(N= \\
316)\end{array}$ & $\begin{array}{c}R \\
\left(\begin{array}{c}R= \\
\left.33^{b}\right)\end{array}\right.\end{array}$ & $O R^{a}$ & $90 \% \mathrm{Cl}$ & $\begin{array}{c}C \\
(N=) \\
\left.14^{b}\right)\end{array}$ & $\begin{array}{c}R \\
(N= \\
\left.19^{b}\right)\end{array}$ & $\mathrm{OR}^{\mathrm{a}}$ & $90 \% \mathrm{Cl}$ & $\begin{array}{c}C \\
(N= \\
\left.12^{b}\right)\end{array}$ & $\begin{array}{c}R \\
(N= \\
\left.17^{b}\right)\end{array}$ & $\mathrm{OR}^{\mathrm{a}}$ & $90 \% \mathrm{Cl}$ \\
\hline Solvents & 12 & 14 & 1.0 & $0.4-2.4$ & 5 & 8 & 0.9 & $0.1-4.7$ & 7 & 2 & $7.9^{c}$ & $1.8-44.9$ & 4 & 1 & 4.5 & $0.5-76.0$ \\
\hline High-frequency & 5 & 4 & 1.2 & $0.4-4.4$ & 2 & 5 & 0.5 & $0.0-3.6$ & 3 & - & $\infty$ & $0.4-\infty$ & 3 & 1 & 4.5 & $0.5-76.0$ \\
\hline $\begin{array}{l}\text { Solvents or products } \\
\text { containing solvents }\end{array}$ & 15 & 14 & 1.4 & $0.6-3.2$ & 6 & 9 & 1.1 & $0.2-5.2$ & 8 & 3 & 6.8 & $0.7-128.3$ & 4 & 1 & 4.5 & $0.5-76.0$ \\
\hline High-frequency & 8 & 4 & 2.0 & $0.7-6.7$ & 3 & 5 & 0.8 & $0.1-4.1$ & 4 & 1 & 2.2 & $0.2-40.1$ & 3 & 1 & 4.5 & $0.5-76.0$ \\
\hline Detergents & 10 & 11 & 0.8 & $0.3-2.0$ & 4 & 2 & 2.2 & $0.4-14.5$ & 5 & 4 & 3.0 & $0.5-21.7$ & 3 & 2 & 2.3 & $0.4-13.7$ \\
\hline Desinfectants & 11 & 14 & 0.9 & $0.4-2.0$ & 4 & 5 & 0.4 & $0.0-2.7$ & 6 & 3 & 3.4 & $0.4-50.4$ & 3 & 2 & 2.6 & $0.4-16.9$ \\
\hline Work in hospital & 6 & 10 & 0.9 & $0.3-2.7$ & 2 & 4 & 0.3 & $0.0-2.2$ & 2 & 2 & 0.5 & $0.0-11.7$ & 2 & 1 & 1.5 & $0.1-28.5$ \\
\hline $\begin{array}{l}\text { Work as a } \\
\text { cleaner, janitor }\end{array}$ & 4 & 5 & 0.6 & $0.2-1.9$ & - & 1 & 0.0 & $0.0-16.0$ & 4 & - & $\infty$ & $1.5-\infty$ & 1 & 1 & 1.0 & $0.0-23.3$ \\
\hline
\end{tabular}

a OR adjusted for residential area, age, and socioeconomic status of the mother.

b Number of women employed at the beginning of pregnancy.

c Crude OR (adjusted OR was technically infinite).

Table 6. Exposure and work during pregnancy for mothers of children with musculoskeletal, chromosomal, cardiac, and multiple malformations. ( $C=$ cases, $\mathrm{R}=$ referents, $\mathrm{OR}=$ odds ratio, $90 \% \mathrm{Cl}=90 \%$ confidence interval)

\begin{tabular}{|c|c|c|c|c|c|c|c|c|c|c|c|c|c|c|c|c|}
\hline \multirow[b]{2}{*}{ Exposure } & \multicolumn{4}{|c|}{$\begin{array}{c}\text { Musculoskeletal } \\
\text { (85 pairs) }\end{array}$} & \multicolumn{4}{|c|}{$\begin{array}{l}\text { Chromosomal } \\
\text { (91 pairs) }\end{array}$} & \multicolumn{4}{|c|}{$\begin{array}{l}\text { Cardiac } \\
\text { (30 pairs) }\end{array}$} & \multicolumn{4}{|c|}{$\begin{array}{c}\text { Multiple } \\
\text { (51 pairs) }\end{array}$} \\
\hline & $\begin{array}{c}C \\
(N= \\
51 b)\end{array}$ & $\begin{array}{c}R \\
(N= \\
\left.54^{b}\right)\end{array}$ & $\mathrm{OR}^{\mathrm{a}}$ & $90 \% \mathrm{Cl}$ & $\begin{array}{c}\mathrm{C} \\
(\mathrm{N}= \\
\left.53^{b}\right)\end{array}$ & $\begin{array}{c}\mathrm{R} \\
(\mathrm{N}= \\
\left.68^{\mathrm{b}}\right)\end{array}$ & $\mathrm{OR}^{\mathrm{a}}$ & $90 \% \mathrm{Cl}$ & $\begin{array}{c}C \\
(N= \\
\left.22^{b}\right)\end{array}$ & $\begin{array}{c}R \\
(N= \\
\left.21^{b}\right)\end{array}$ & $O R^{a}$ & $90 \% \mathrm{Cl}$ & $\begin{array}{c}\mathrm{C} \\
(\mathrm{N}= \\
\left.30^{\mathrm{b}}\right)\end{array}$ & $\begin{array}{c}\mathrm{R} \\
(\mathrm{N}= \\
\left.38^{\mathrm{b}}\right)\end{array}$ & $\mathrm{OR}^{\mathrm{a}}$ & $90 \% \mathrm{Cl}$ \\
\hline Solvents & 11 & 10 & 1.6 & $0.7-4.1$ & 7 & 13 & 0.7 & $0.2-1.7$ & 5 & 4 & 1.3 & $0.3-6.2$ & 7 & 5 & 2.8 & $0.8-11.0$ \\
\hline High-frequency & 5 & 2 & 1.8 & $0.4-11.2$ & 5 & 6 & 1.0 & $0.3-3.7$ & 3 & 3 & 1.2 & $0.2-9.2$ & 3 & 1 & 3.9 & $0.4-66.5$ \\
\hline $\begin{array}{l}\text { Solvents or products } \\
\text { containing solvents }\end{array}$ & 12 & 10 & 1.7 & $0.7-4.2$ & 7 & 13 & 0.7 & $0.2-1.7$ & 6 & 4 & 1.3 & $0.3-6.2$ & 8 & 5 & 2.8 & $0.8-11.0$ \\
\hline High-frequency & 6 & 2 & 2.0 & $0.4-11.9$ & 5 & 6 & 1.0 & $0.3-3.7$ & 4 & 3 & 1.2 & $0.2-9.2$ & 4 & 1 & 3.9 & $0.4-66.5$ \\
\hline Detergents & 10 & 7 & 2.4 & $0.8-7.1$ & 3 & 5 & 1.2 & $0.3-5.0$ & 3 & 1 & 3.4 & $0.4-54.9$ & 7 & 5 & 2.2 & $0.6-8.1$ \\
\hline Desinfectants & 12 & 9 & 2.0 & $0.8-5.2$ & 4 & 8 & 0.5 & $0.2-1.8$ & 6 & 4 & 1.3 & $0.3-6.5$ & 8 & 5 & 2.5 & $0.7-8.6$ \\
\hline Work in hospital & 5 & 7 & 1.5 & $0.5-4.9$ & 3 & 5 & 1.0 & $0.2-3.8$ & 4 & 3 & 1.8 & $0.3-12.3$ & 2 & 5 & 0.5 & $0.1-2.6$ \\
\hline $\begin{array}{l}\text { Work as a } \\
\text { cleaner, janitor }\end{array}$ & 6 & 1 & 5.3 & $0.9-67.6$ & 1 & 2 & 0.5 & $0.0-5.7$ & 2 & - & $\infty$ & $0.2-\infty$ & 4 & 1 & 3.6 & $0.4-60.2$ \\
\hline
\end{tabular}

a OR adjusted for residential area, age, and socioeconomic status of the mother.

b Number of women employed at the beginning of pregnancy.

the different groups of malformations. The analysis was restricted to women employed at the beginning of pregnancy. There was a higher proportion of mothers exposed to solvents and of mothers working as cleaners among the cases with oral clefts.

The results concerning exposure to solvents for at least six months at any time during the whole worklife (before and during pregnancy), restricted to women having ever been employed, are presented in table 7 . In the groups of digestive anomalies and multiple anomalies there was an excess of mothers exposed to solvents during their worklife $(P<0.10)$. The excess observed in the group of oral clefts was not statistically significant. It must be noted that these results are not entirely independent since 15 oral clefts out of 29 also had multiple anomalies, as did 15 digestive anomalies out of 22 . Nineteen digestive anomalies out of 22 were gastrointestinal atresia. No other exposure occurring during the whole worklife was found to be associated with an excess risk of congenital anomalies.
Only a few women (less than $3 \%$ ) reported contact with a chemical during hobbies in their first trimester of pregnancy. These exposures were not analyzed further.

\section{Discussion}

The present study suggests an association between maternal occupational exposure to solvents and some groups of birth defects such as oral clefts, anomalies of the digestive system, or multiple anomalies. Some of these groups were among those which were previously found to be associated with maternal exposure to solvents $(7)$ or laboratory work $(9,10)$. Cleaning work was more often done by the mothers of cases with oral clefts. This occupational group included various jobs such as nursing aides, chambermaids, cleaners, and janitors. To our knowledge, this group has never been studied for reproductive problems, other than in the study by McDonald et al (16), who reported a 
Table 7. Occupational exposure to "pure" solvents during or before pregnancy.

\begin{tabular}{|c|c|c|c|c|c|c|c|}
\hline \multirow{2}{*}{$\begin{array}{l}\text { Group of } \\
\text { malformations }\end{array}$} & \multirow{2}{*}{$\begin{array}{l}\text { Pairs } \\
\text { (N) }\end{array}$} & \multicolumn{2}{|c|}{ Cases } & \multicolumn{2}{|c|}{ Referents } & \multirow{2}{*}{$\begin{array}{l}\text { Odds } \\
\text { ratioc }\end{array}$} & \multirow{2}{*}{$\begin{array}{l}90 \% \text { confidence } \\
\text { interval }\end{array}$} \\
\hline & & $\begin{array}{l}\text { Employed } \\
(N)\end{array}$ & $\begin{array}{l}\text { Exposed } \\
\text { (N) }\end{array}$ & $\begin{array}{l}\text { Employed }^{a} \\
(\mathrm{~N})\end{array}$ & $\begin{array}{l}\text { Exposed } \\
(\mathrm{N})\end{array}$ & & \\
\hline $\begin{array}{l}\text { Central nervous } \\
\text { system }\end{array}$ & 83 & 67 & 15 & 72 & 17 & 0.9 & $0.4-1.9$ \\
\hline Urinary & 51 & 39 & 7 & 43 & 11 & 0.9 & $0.3-2.6$ \\
\hline Oral clefts & 29 & 21 & 8 & 24 & 3 & 3.3 & $0.8-18.1$ \\
\hline Digestive & 22 & 21 & 8 & 19 & 1 & 11.9 & $2.0-148.8$ \\
\hline Musculoskeletal & 85 & 72 & 16 & 69 & 13 & 1.4 & $0.7-3.1$ \\
\hline Chromosomal & 91 & 82 & 14 & 80 & 20 & 0.7 & $0.3-1.4$ \\
\hline Cardiac & 30 & 26 & 6 & 25 & 4 & 1.7 & $0.4-7.6$ \\
\hline Multiple & 51 & 43 & 12 & 44 & 5 & 4.5 & $1.4-16.9$ \\
\hline
\end{tabular}

a Mothers ever employed.

b Mothers ever occupationally exposed to solvents.

c Odds ratio adjusted for residential area, age, and socioeconomic status of the mother.

higher risk of low birthweight. The group, however, is closely correlated with a lower socioeconomic status, the effect of which can hardly be separated from the effect of occupational exposures on reproductive problems.

Some of the maternity hospitals in which our study was conducted were specialized units acting as referral centers for prenatal diagnosis and high-risk pregnancies. For this reason, the percentage of therapeutic abortions in our sample was high, especially in Paris ( $57.8 \%$ versus $22.2 \%$ in Marseille). The contribution of therapeutic abortion was also high in relation to some specific groups of anomalies, such as chromosomal anomalies or central nervous system defects, for which prenatal diagnosis is particularly efficient. We believe that the inclusion of therapeutic abortions in our case sample is highly justified at a period when prenatal diagnosis has become more widely accessible.

The cases and referents differed with respect to several characteristics. For example, older mothers ( $>35$ years) were more frequent among the cases (and this was especially true in the group of chromosomal anomalies); the mothers of cases originated more often from outside France; the mothers of cases were more often unemployed at the time of pregnancy; and the mothers of cases had a higher parity than the mothers of the referents. Socioeconomic status of the family, as measured by the last occupation of the father (or the mother), was higher among the referents. These findings draw an overall pattern of differential access to maternities among the cases and referents. A high proportion of cases was admitted to these units for medical reasons, irrespective of their socioeconomic status, whereas referents without a medical problem and with access to these facilities were, on the average, of a higher socioeconomic status. Socioeconomic status, related to probability of occupational exposure, should then be controlled for. This problem was accounted for in several ways. All of the comparisons were adjusted for area of residence of the mother at the time of the study on one hand (controlling for hospital and, in Paris, for distance from hospital) and for socioeconomic status of the mother on the other. Furthermore, comparisons of occupational exposures were restricted to women employed at the time of pregnancy for the study of exposures occurring during pregnancy and to women ever employed for exposures during the whole worklife.

Exposure to specific compounds was assessed without knowledge of the case-referent status by an industrial hygienist who reviewed the description of the work given by the women. The same interviewer was in charge of interviewing both the case and the corresponding referent. Thus exposure was assessed according to the type of job performed and to the knowledge of the expert, and there was no reliance on a direct report of exposure by the woman herself. Such questions were asked during the interview, but the answers were not given to the expert. We then were able to compare the answers given by the woman herself with the evaluation made by the expert. On the average, only one-third $(31 \%)$ of the women who were considered by the expert to be highly exposed to solvents reported such an exposure. This percentage was higher for the referents $(40 \%)$ than for the cases $(21 \%)$. This difference might have led to an underestimation of the risk if the women's answers had been used as a measure of exposure. The procedure used to evaluate exposure from job description, independently of direct report by the woman, seems to be a good protection against recall bias. Estimation of the precise timing of exposure was not possible. We can assume however that exposure during pregnancy occurred at least at the beginning of pregnancy. Significant results found in association with exposure during the whole worklife are hard to interpret in biological terms and may merely reflect an increase in statistical power in comparison with the study of exposures during pregnancy, since 
the estimates were of the same order of magnitude in both cases.

Compared with the findings of other studies, our results do not confirm the association found in Finland between exposure to solvents and central nervous system anomalies (6), nor the association with urinary anomalies observed in Canada (8). In the group of urinary anomalies, we did not include anomalies such as hypospadias if they were isolated, although they represented the majority of urinary anomalies in the Canadian study. This difference might explain some of the discrepancy. Another explanation refers to statistical power considerations. Studying subgroups of anomalies and restricting the analysis to employed women increases specificity but leaves us with small numbers. These small numbers, added to the possibility of exposure misclassification, reduces the statistical power of the comparisons.

However, despite the small sample size, our results indicated a possible link between oral clefts and solvent exposure, which confirms the observation by Holmberg et al (7). Occupation involving exposure to solvents might also increase the risk of gastrointestinal atresia; such a possible association has already been mentioned for laboratory workers (9). The suggestive results found for multiple anomalies confirm that this particular group of anomalies might be of special interest in the detection of new teratogens in the environment and deserves further study.

Our survey did not allow a precise estimation of the timing of exposure nor a study of dose-response relationships. Due to the small numbers, the estimates of effect were not very precise and at the limit of statistical significance $(P<0.10)$. In addition, the type of recruitment used might have introduced some confounding which was not entirely accounted for in the analysis. Despite these restrictions, the suggestive results found prompted the planning of a European study on this topic. Six European registers of birth defects, members of EUROCAT [European Registration for Congenital Anomalies and Twins, EEC (European Economic Community) Concerted Action Project], are now participating in a case-referent study in which occupational exposure during pregnancy will be evaluated by local industrial hygienists. Standardization of exposure measurement will be done in the four European countries involved. This study started in 1989 and should include up to 1000 cases of major birth defects.

\section{Acknowledgments}

This work was supported by a grant from the National Center for Scientific Research (CNRS), Programme PIREN.
We thank Ms N Le Moual (INSERM U 170) for her technical assistance, Ms I Laffont-Faust for evaluating the occupational exposures, Ms C du Mazaubrun, Ms F Maillard (INSERM U 149), Ms C Julian (INSERM $\mathrm{U}$ 242) and all the interviewers and midwives in Paris and Marseille who participated in the study, and Ms E Przybilski for typing the manuscript.

\section{References}

1. Tsubaki T, Irukayama K. Congenital Minamata disease. In: Minamata disease: methylmercury poisoning in Minamata and Niigata, Japan. Amsterdam: Elsevier, 1977:209-233.

2. Amin-Zaki L, Majeed MA, Elhassani SB, Clarkson TW, Greenwood MR, Doherty RA. Prenatal methylmercury poisoning. Am $\mathrm{J}$ Dis Child 1979;133:172-7.

3. Erickson JD, Cochran WM, Anderson CE. Parental occupation and birth defects. Contrib Epidemiol Biostat 1979;1:107-17.

4. Hemminki K, Mutanen P, Luoma K, Saloniemi I. Congenital malformation by the parental occupation in Finland. Int Arch Occup Environ Health 1980;46:93-8.

5. Taskinen HK. Effects of parental occupational exposures on spontaneous abortion and congenital malformation. Scand J Work Environ Health 1990;16:297-314.

6. Holmberg PC, Nurminen M. Congenital defects of CNS and occupational factors during pregnancy: a casereferent study. Am J Ind Med 1980;1:167-76.

7. Holmberg PC, Hernberg S, Kurppa K, Riala R, Rantala $\mathrm{K}$. Oral clefts and organic solvent exposure during pregnancy. Int Arch Occup Environ Health 1982;50: $371-6$.

8. McDonald JC, Lavoie J, Cote R, McDonald AD. Chemical exposures at work in early pregnancy and congenital defect: a case-referent study. $\mathrm{Br} \mathrm{J}$ Ind Med 1987; 44:527-33.

9. Meirik O, Källen B, Gauffin U, Ericson A. Major malformations in infants born of women who worked in laboratories while pregnant. Lancet 1979;2:91.

10. Ericson A, Källen B, Meirik O, Westerholm P. Gastrointestinal atresia and maternal occupation during pregnancy. J Occup Med 1982;24:515-8.

11. Olsen J. Risk of exposure to teratogens amongst laboratory staff and painters. Dan Med Bull 1983;30:24-8.

12. Tannenbaum TN, Goldberg RJ. Exposure to anesthetic gases and reproductive outcome: a review of the epidemiologic literature. J Occup Med 1985;27:659-68.

13. Baltzar B, Ericson A, Källen B. Delivery outcome in women employed in medical occupations in Sweden. J Occup Med 1979;21:543-8.

14. Källen B. Congenital malformations: infants with more than one malformation diagnosis. In: Epidemiology of human reproduction, Boca Raton, FL: CRC Press, Inc, 1988:31-5.

15. CYTEL Software Corporation. StatXact: statistical software for exact non parametric inference: user manual. Cambridge, MA: CYTEL Software Corporation, 1989.

16. McDonald AD, McDonald JC, Armstrong B, Cherry $\mathrm{N}$, Delorme $\mathrm{C}$, Nolin $\mathrm{AD}$, et $-\mathrm{l}$. Occupation and pregnancy outcome. Br J Ind N.ed 1987; 44:521-6.

Received for publication: 10 December 1990 